\title{
Nanoscale
}

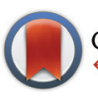

CrossMark

Cite this: Nanoscale, 2015, 7, 18129

\section{Synthesis, structure and gas-phase reactivity of the mixed silver hydride borohydride nanocluster $\left[\mathrm{Ag}_{3}\left(\mu_{3}-\mathrm{H}\right)\left(\mu_{3}-\mathrm{BH}_{4}\right) \mathrm{L}_{3}^{\mathrm{Ph}}\right] \mathrm{BF}_{4}\left(\mathrm{~L}^{\mathrm{Ph}}=\right.$ bis(diphenylphosphino)methane) $\dagger$}

\author{
Athanasios Zavras, ${ }^{a}$ Alireza Ariafard, ${ }^{\text {a,b,c }}$ George N. Khairallah, ${ }^{a}$ Jonathan M. White, ${ }^{a}$ \\ Roger J. Mulder, ${ }^{d}$ Allan J. Canty ${ }^{\mathrm{b}}$ and Richard A. J. O'Hair*a
}

Borohydrides react with silver salts to give products that span multiple scales ranging from discrete mononuclear compounds through to silver nanoparticles and colloids. The cluster cations $\left[\mathrm{Ag}_{3}(\mathrm{H})\left(\mathrm{BH}_{4}\right) \mathrm{L}_{3}\right]^{+}$are observed upon electrospray ionization mass spectrometry of solutions containing sodium borohydride, silver( $\left(\right.$ ) tetrafluoroborate and bis(dimethylphosphino)methane $\left(\mathrm{L}^{\mathrm{Me}}\right)$ or bis(diphenylphosphino)methane $\left(\mathrm{L}^{\mathrm{Ph}}\right)$. By adding $\mathrm{NaBH}_{4}$ to an acetonitrile solution of $\mathrm{AgBF}_{4}$ and $\mathrm{L}^{\mathrm{Ph}}$, cooled to $\mathrm{ca}$. $-10{ }^{\circ} \mathrm{C}$, we have been able to isolate the first mixed silver hydride borohydride nanocluster, $\left[\mathrm{Ag}_{3}\left(\mu_{3}-\mathrm{H}\right)\left(\mu_{3}-\mathrm{BH}_{4}\right) \mathrm{L}_{3}\right] \mathrm{BF} \mathrm{F}_{4}$, and structurally characterise it via $\mathrm{X}$-ray crystallography. Combined gas-phase experiments $\left(\mathrm{L}^{\mathrm{Me}}\right.$ and $\left.\mathrm{L}^{\mathrm{Ph}}\right)$ and DFT calculations $\left(\mathrm{L}^{\mathrm{Me}}\right)$ reveal how loss of a ligand from the cationic complexes $\left[\mathrm{Ag}_{3}(\mathrm{H})\left(\mathrm{BH}_{4}\right) \mathrm{L}_{3}\right]^{+}$provides a change in geometry that facilitates subsequent loss of $\mathrm{BH}_{3}$ to produce the dihydride clusters, $\left[\mathrm{Ag}_{3}(\mathrm{H})_{2} \mathrm{~L}_{n}\right]^{+}$ ( $n=1$ and 2). Together with the results of previous studies (Girod et al., Chem. - Eur. J., 2014, 20, 16626), this provides a direct link between mixed silver hydride/borohydride nanoclusters, silver hydride nanoclusters, and silver nanoclusters.

Received 21st August 2015 Accepted 5th October 2015 DOI: $10.1039 / \mathrm{c} 5 \mathrm{nr} 05690$ j www.rsc.org/nanoscale via hydrogen and $\mathrm{BH}_{3}$ loss (eqn (2)). ${ }^{2-4}$ Hydrogen can also be liberated via reaction with methanol (eqn (3)). Ab initio calculations suggested that the decomposition of $\mathrm{AgBH}_{4}$ should yield silver hydride (eqn (4)). ${ }^{23}$ Finally, there have been several reports that discrete mononuclear complexes of $\mathrm{AgBH}_{4}$ could be isolated when phosphine ligands were employed, ${ }^{2-4}$ ultimately leading to the X-ray crystallographic characterization of $\left(\mathrm{Ph}_{2} \mathrm{MeP}\right)_{3} \mathrm{AgBH}_{4}$ (Scheme 1(a)).

$$
\begin{gathered}
\mathrm{AgClO}_{4}+\mathrm{LiBH}_{4} \rightarrow \mathrm{AgBH}_{4}+\mathrm{LiClO}_{4} \\
\mathrm{AgBH} \\
4 \\
\mathrm{AgBH}_{4}+3 \mathrm{Ag}+0.5 \mathrm{H}_{2}+\mathrm{BH}_{3} \\
\mathrm{AgBH}_{4} \rightarrow \mathrm{AgH}+\mathrm{BH}_{3}
\end{gathered}
$$

In the last few years, several new silver nanoclusters have been isolated from reaction mixtures containing silver salts, sodium borohydride and either anionic ligands or neutral ligands and structurally characterised via X-ray crystallography. Structural reports include (i) silver hydride clusters $\left[\mathrm{Ag}_{2}\left(\mu_{2}-\mathrm{H}\right) \mathrm{L}_{2}\right]$ $\mathrm{BF}_{4}{ }^{8}$ (where $\mathrm{L}=1,3$-bis(2,6-diisopropylphenyl)imidazolin2-ylidene (Scheme 1(b)), $\left[\mathrm{Ag}_{3}\left(\mu_{3}-\mathrm{H}\right)\left(\mu_{3}-\mathrm{Cl}\right) \mathrm{L}^{\mathrm{Ph}}\right] \mathrm{BF}_{4}{ }^{9}$ and $\left[\mathrm{Ag}_{3}\left(\mu_{3}-\mathrm{H}\right) \mathrm{L}^{\mathrm{Ph}}\right]\left(\mathrm{BF}_{4}\right)_{2}{ }^{10}$ (where $\mathrm{L}^{\mathrm{Ph}}=$ bis(diphenylphosphino)methane), $\left[\left\{\mathrm{Ag}_{7}\left(\mu_{4}-\mathrm{H}\right)\left(\mathrm{E}_{2} \mathrm{P}(\mathrm{OR})_{2}\right\}_{6}\right]\left(\mathrm{R}={ }^{i} \mathrm{Pr}, \mathrm{E}=\mathrm{Se}\right),{ }^{18}\right.$ 
(a)

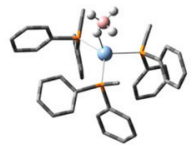

(c)

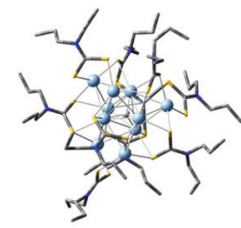

(e)

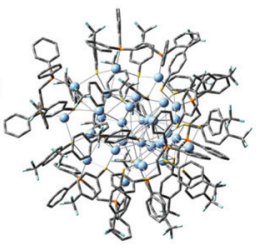

$\left(\mathrm{Ph}_{2} \mathrm{MeP}\right)_{3} \mathrm{AgBH}_{4}$

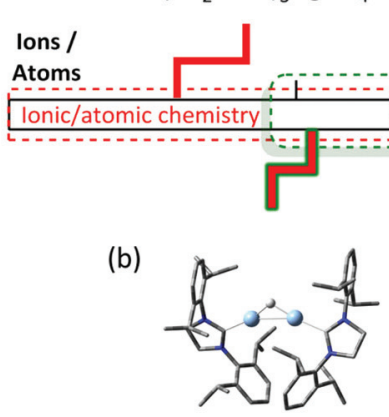

$\left[\mathrm{Ag}_{2}\left(\mu_{2}-\mathrm{H}\right) \mathrm{L}_{2}\right]^{+}$

\section{$\left[\mathrm{Ag}_{11}(\mathrm{H})\left(\mathrm{S}_{2} \mathrm{P}(\mathrm{OEt})_{2}\right)_{9}\right]^{+}$}

$\left\{\mathrm{Ag}_{32}(\mathrm{dppe})_{5}\left(\mathrm{SC}_{6} \mathrm{H}_{4} \mathrm{CF}_{3}\right)_{24}\right\}^{2-}$

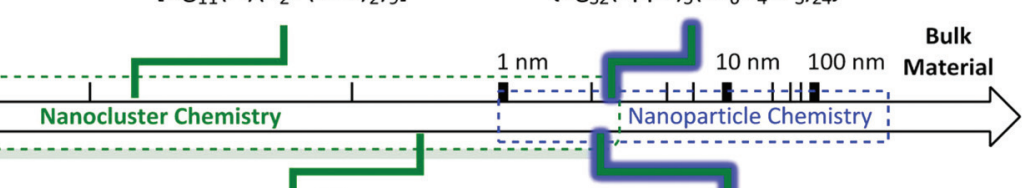

(d)

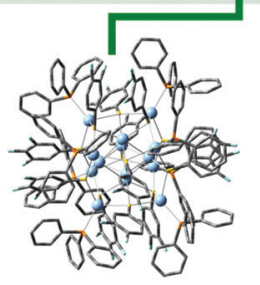

$\mathrm{Ag}_{14}\left(\mathrm{SC}_{6} \mathrm{H}_{3} \mathrm{~F}_{2}\right)_{12}\left(\mathrm{PPh}_{3}\right)_{8}$ (f)

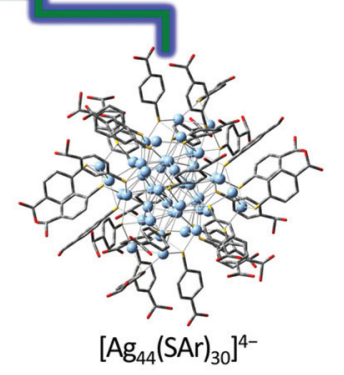

Scheme 1 Reactions of $\mathrm{BH}_{4}{ }^{-}$with silver salts to give products spanning multiple scales. (a)-(f) represent discrete isolated species whose structures have been determined via X-ray crystallography. The scale indicates ionic interactions or the outermost diameter of each silver cluster not inclusive of ligands. Counterions and hydrogen atoms have been omitted for clarity.

$\left[\mathrm{Ag}_{8} \mathrm{H}\left(\mathrm{S}_{2} \mathrm{P}(\mathrm{OEt})_{2}\right)_{6}\right]^{+5}$, and $\left[\mathrm{Ag}_{11}(\mathrm{H})\left(\mathrm{S}_{2} \mathrm{P}(\mathrm{OEt})_{2}\right)_{9}\right]^{+}$(Scheme $\left.1(\mathrm{c})\right),{ }^{6,7}$ (ii) the silver clusters $\mathrm{Ag}_{14}\left(\mathrm{SC}_{6} \mathrm{H}_{3} \mathrm{~F}_{2}\right)_{12}\left(\mathrm{PPh}_{3}\right)_{8}$ (Scheme $\left.1(\mathrm{~d})\right)^{12}$ $\mathrm{Ag}_{16}(\mathrm{dppe})_{4}\left(\mathrm{SC}_{6} \mathrm{H}_{3} \mathrm{~F}_{2}\right)_{14}, \quad\left\{\mathrm{Ag}_{32}(\mathrm{dppe})_{5}\left(\mathrm{SC}_{6} \mathrm{H}_{4} \mathrm{CF}_{3}\right)_{24}\right\}^{2-}$ (dppe $=$ 1,2-bis(diphenylphosphino) ethane, Scheme $1(\mathrm{e})),{ }^{14}$ $\left[\mathrm{Ag}_{44}\left(\mathrm{SAr}_{30}\right]^{4-}\right.$ (where ArS is an arylsulfide, Scheme $\left.1(\mathrm{f})\right),{ }^{13}$ $\left[\mathrm{Ag}_{21}\left\{\mathrm{~S}_{2} \mathrm{P}\left(\mathrm{O}^{i} \mathrm{Pr}\right)_{2}\right\}_{12}\right]^{+},{ }^{15} \mathrm{Ag}_{29}(\mathrm{BDT})_{12}\left(\mathrm{PPh}_{3}\right)_{4}(\mathrm{BDT}=1,3$-benzenedithiol $)^{16}$ and $\left[\mathrm{Ag}_{25}(\mathrm{SR})_{18}\right]^{-}{ }^{17}$ Importantly, Liu et al. have shown that $\left[\left\{\mathrm{Ag}_{7}\left(\mu_{4}-\mathrm{H}\right)\left(\mathrm{E}_{2} \mathrm{P}(\mathrm{OR})_{2}\right\}_{6}\right](\mathrm{E}=\mathrm{Se}, \mathrm{S})\right.$ are precursors to further growth into silver nanoparticles. ${ }^{24}$

Here we report the "mass spectrometry directed synthesis" of the first mixed silver hydride/borohydride cluster $\left[\mathrm{Ag}_{3}\left(\mu_{3}-\mathrm{H}\right)-\right.$ $\left.\left(\mu_{3}-\mathrm{BH}_{4}\right) \mathrm{L}_{3} \mathrm{Ph}_{3}\right] \mathrm{BF}_{4},{ }^{25-27}$ and its structural characterization by X-ray crystallography. DFT calculations indicate that the loss of a ligand (L) under collision induced dissociation (CID) conditions results in a change in cluster geometry that facilitates decomposition of the ligated $\mathrm{BH}_{4}^{-}$via loss of $\mathrm{BH}_{3}$ (cf. eqn (2)).

\section{Results and discussion}

Electrospray ionization mass spectrometry (ESI/MS) was used to monitor the identity of cationic silver clusters formed upon mixing silver(I) tetrafluoroborate with diphosphine ligands in cooled acetonitrile solutions and subsequently treating with excess $\mathrm{NaBH}_{4}$. The ligands bis(diphenylphosphino)methane $\left(\mathrm{L}^{\mathrm{Ph}}\right)$ and bis(dimethylphosphino)methane $\left(\mathrm{L}^{\mathrm{Me}}\right)$ were added to an acetonitrile solution of $\mathrm{AgBF}_{4}(1.9 \mathrm{mg}, 5 \mathrm{mM})$ with a ligand-to-metal ratio of $1: 1$ giving a clear solution. Addition of 15 equivalents of $\mathrm{NaBH}_{4}$ to each of these solutions gave an immediate colour change from colourless to light yellow for both $\mathrm{L}^{\mathrm{Ph}}$ and $\mathrm{L}^{\mathrm{Me}}$. ESI/MS analysis 5 minutes after the addition of $\mathrm{NaBH}_{4}$ are shown in Fig. 1. The bulkier $\mathrm{L}^{\mathrm{Ph}}$ ligand yields the abundant peak $\left[\mathrm{Ag}_{3}(\mathrm{H})\left(\mathrm{BH}_{4}\right) \mathrm{L}_{3}^{\mathrm{Ph}}\right]^{+} m / z 1493$ (Fig. 1a), confirmed by high resolution mass spectrometry experiments (ESI Fig. S1a and $\left.\mathrm{b}_{\dagger}\right)$. In contrast the $\mathrm{L}^{\mathrm{Me}}$ yields a mixture of silver clusters assigned as $\left[\mathrm{Ag}_{3}(\mathrm{H}) \mathrm{L}_{3}^{\mathrm{Me}}\right]^{2+} m / z 366,\left[\mathrm{Ag}_{3}(\mathrm{H})\left(\mathrm{BH}_{4}\right) \mathrm{L}_{3}^{\mathrm{Me}}\right]^{+}$

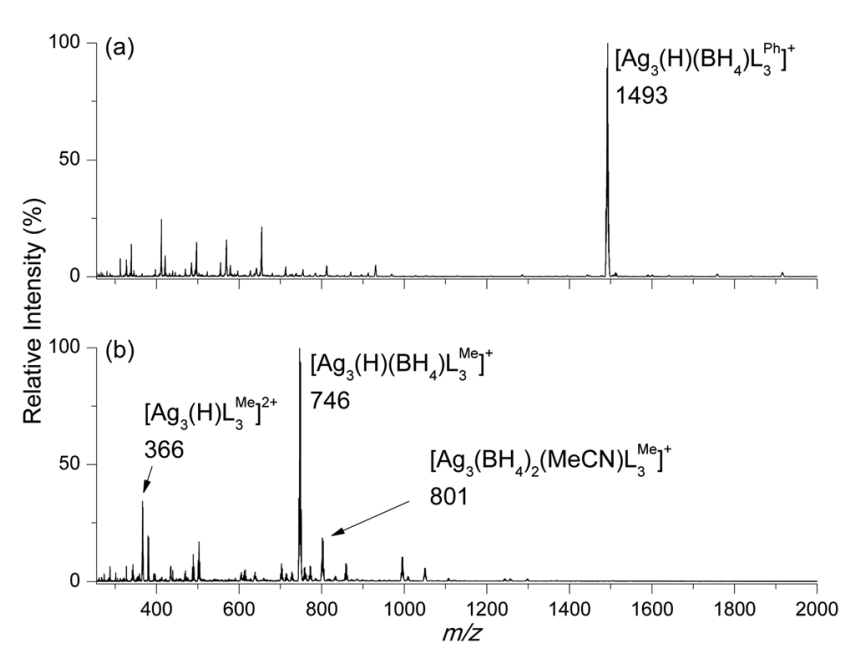

Fig. 1 Full LTQ ESI/MS for solution phase synthesis of silver hydride clusters protected by diphosphine ligands: (a) $L^{\mathrm{Ph}}$; (b) $L^{\mathrm{Me}}$. Solutions containing condensed phase silver clusters were diluted to $50 \mu \mathrm{M}$ in acetonitrile. Spectra were recorded 5 minutes after the addition of $\mathrm{NaBH}_{4}$. The most intense peak in the cluster represents the $\mathrm{m} / \mathrm{z}$ value. 
$m / z 746$ (Fig. 1b, ESI Fig. S2 $\dagger$ ) and $\left[\mathrm{Ag}_{3}\left(\mathrm{BH}_{4}\right)_{2}\left(\mathrm{MeCN} \mathrm{L}_{3}^{\mathrm{Me}}\right]^{+} \mathrm{m} / z\right.$ 801. Since clusters formed from $\mathrm{L}^{\mathrm{Ph}}$ were less prone to decomposition reactions in solution compared to those formed from $\mathrm{L}^{\mathrm{Me}},{ }^{28}$ the synthesis of crystalline material suitable for characterization was pursued for $\mathrm{L}^{\mathrm{Ph}}$.

\section{Structural characterization of (1) by ESI/MS, NMR and IR spectroscopy and X-ray crystallography}

The crystals of (1) formed in the bulk synthesis were first analysed via ESI/MS in both the positive and negative ion mode. The former gave an almost identical mass spectrum to that shown in Fig. 1a (data not shown), while the latter gave an abundant signal due to the $\mathrm{BF}_{4}{ }^{-}$counter ion (ESI Fig. S3 $\dagger$ ). IR spectroscopy confirmed the presence of both $\mathrm{BF}_{4}{ }^{-}$and $\mathrm{BH}_{4}{ }^{-}$(ESI Fig. $\mathrm{S} 4 \dagger$ ).

We next attempted to characterise 1 via various NMR experiments (ESI Fig. S5-S16†). 1 was dissolved into cold $\mathrm{CD}_{3} \mathrm{CN}$ to produce a saturated solution and this solution immediately introduced into the pre-cooled NMR probe at $-15{ }^{\circ} \mathrm{C}$. The ${ }^{1} \mathrm{H}$ NMR spectrum collected at $-15{ }^{\circ} \mathrm{C}$ displayed a very broad multiplet centred at $0.5 \mathrm{ppm}$, attributed to coordinated $\mathrm{BH}_{4}$, from which no fine structure could be resolved (ESI Fig. S5 $\dagger$ ). This may be due to (i) the fluxional nature of the binding of $\mathrm{BH}_{4}$, (ii) the complex splitting patterns due to spin-active nuclei and isotopomers of silver $\left({ }^{107 / 109} \mathrm{Ag}\right)$ and boron $\left({ }^{10 / 11} \mathrm{~B}\right)$ and (iii) the influence of the quadrupolar ${ }^{10} \mathrm{~B}$ nucleus. This signal collapsed into a broad singlet at $0.5 \mathrm{ppm}$ under ${ }^{11}$ B-decoupling (ESI Fig. S6 and S7 $\dagger$ ). There was no apparent change to the signals upon ${ }^{31} \mathrm{P}$-decoupling (ESI Fig. S8 and $\mathrm{S} 9 \dagger)$. The ${ }^{1} \mathrm{H}$ NMR spectrum further displayed a broad multiplet centred at $4.5 \mathrm{ppm}$ attributed to the coordinated hydride (ESI Fig. S5 $\dagger$ ), the peaks of which sharpened slightly under ${ }^{31}$ P-decoupling (ESI Fig. S8 and S9 ). The $^{1} \mathrm{H}$-decoupled

${ }^{31} \mathrm{P}$ NMR spectrum displayed a broad peak at $0.56 \mathrm{ppm}$, shifted downfield from the free ligand resonance at $23.1 \mathrm{ppm}$ (ESI Fig. S10 $\dagger$ ). The ${ }^{1} \mathrm{H}$-decoupled ${ }^{11} \mathrm{~B}$ NMR spectrum displays two resonances at 0.57 and $41.49 \mathrm{ppm}$ attributable to $\mathrm{BF}_{4}{ }^{-}$and $\mathrm{BH}_{4}$, respectively (ESI Fig. S11†), as confirmed via the ${ }^{19} \mathrm{~F}^{11} \mathrm{~B}$ and ${ }^{1} \mathrm{H}^{-11} \mathrm{~B}$ HSQC NMR experiments (ESI Fig. S12 and $\mathrm{S} 13 \dagger$ respectively). The ${ }^{1} \mathrm{H}$-decoupled ${ }^{19} \mathrm{~F}$ NMR spectrum displays a resonance at $-150.16 \mathrm{ppm}$ corresponding to $\mathrm{BF}_{4}^{-}$(ESI Fig. S14 $\dagger$ ). The ${ }^{1} \mathrm{H}$-decoupled ${ }^{13} \mathrm{C}$ NMR spectrum displays resonances attributable to coordinated phosphine ligand (ESI Fig. S15†).

Heating the sample from $-15{ }^{\circ} \mathrm{C}$ to $+25{ }^{\circ} \mathrm{C}$ in the $\mathrm{NMR}$ probe enabled the collection of ${ }^{1} \mathrm{H}$ data at various temperatures. The most obvious change in the spectra with time at $-15{ }^{\circ} \mathrm{C}$ and then upon heating was the increase in the intensity of the singlet at $4.56 \mathrm{ppm}$ which is attributable to dissolved $\mathrm{H}_{2}$ and the corresponding reduction in the intensity of the coordinated hydride signal (ESI Fig. S16†).

This series of experiments required the preparation of several different samples, as it was noted that $\mathbf{1}$ appears to undergo decomposition/reactions in these highly concentrated solutions, ultimately resulting in precipitation of a black material after approximately 3 hours at $25{ }^{\circ} \mathrm{C}$. This rapid change in solution, even at $-15{ }^{\circ} \mathrm{C}$, precluded the overnight or longer acquisition of a ${ }^{109} \mathrm{Ag}$ NMR spectrum.

$\mathrm{X}$-ray crystallography was used to determine the structure of $\left[\mathrm{Ag}_{3}(\mathrm{H})\left(\mathrm{BH}_{4}\right) \mathrm{L}_{3}^{\mathrm{Ph}}\right] \mathrm{BF}_{4} . \S$ The cation $\left[\mathrm{Ag}_{3}(\mathrm{H})\left(\mathrm{BH}_{4}\right) \mathrm{L}_{3}^{\mathrm{Ph}}\right]^{+}$which has crystallographic 3-fold symmetry, Fig. 2, consists of a trinuclear core with silver(I) ions occupying the vertices of an equilateral triangle.

The $A g(1)-A g(1)$ distances that connect the edges of the triangle are $2.9100(3) \AA$ A. The hydride $\mathrm{H}$ which lies on a crystallographic 3 -fold axis is $0.96 \AA$ displaced from the plane defined by the triangular silver(I) core and is coordinated to all silver(I) ions as a $\mu_{3}$-bridging ligand with a $\mathrm{Ag}(1)-\mathrm{H}$ distance of 1.93(3) $\AA$ and $\mathrm{Ag}(1)-\mathrm{H}-\mathrm{Ag}(1)$ angle of $97.5(3)^{\circ}$. Relative to the

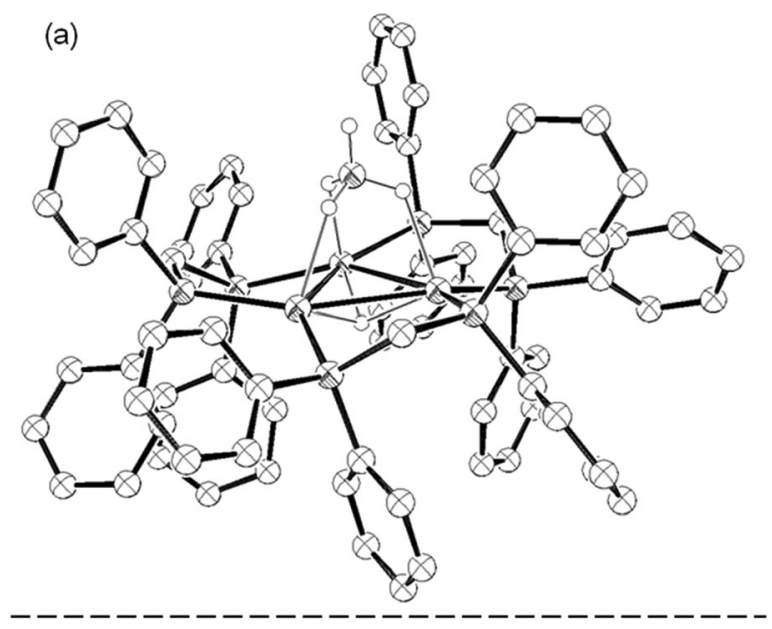

(b)

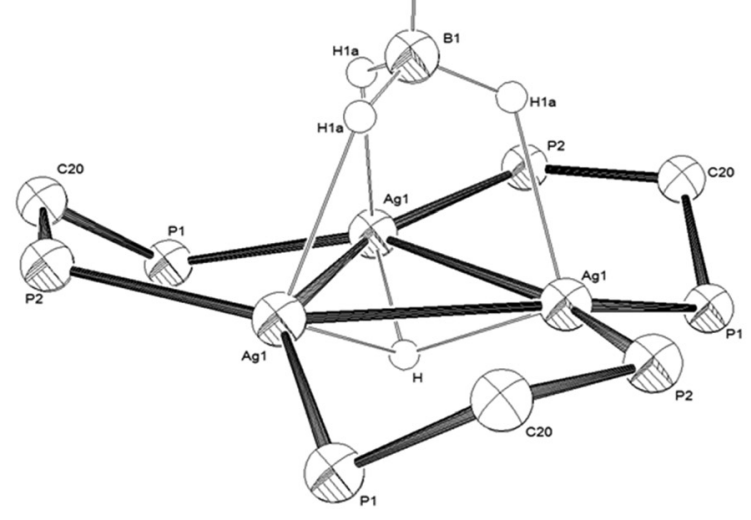

Fig. 2 ORTEP-3 representations of: (a) the cation present in $\left[\mathrm{Ag}_{3}\left(\mu_{3}-\mathrm{H}\right)-\right.$ $\left.\left(\mu_{3}-\mathrm{BH}_{4}\right) \mathrm{L}_{3} \mathrm{Ph}_{3}\right] \mathrm{BF}_{4}$ and, (b) the trinuclear silver hydride/borohydride ' $\mathrm{Ag}_{3}\left(\mu_{3}-\mathrm{H}\right)\left(\mu_{3}-\mathrm{BH}_{4}\right)$ ' core, where phenyl rings are omitted for clarity. Displacement ellipsoids are set at the $50 \%$ probability level. $\mathrm{Ag}(1)-\mathrm{Ag}(1)$ 2.9100(3), $\mathrm{Ag}(1)-P(1)$ 2.4483(5), $\mathrm{Ag}(1)-\mathrm{P}(2)$ 2.4486(5), $\mathrm{Ag}(1)-\mathrm{H}$ 1.93(3), $\mathrm{Ag}(1)-\mathrm{H}(1 \mathrm{a})$ 2.17(3), B(1)-H(1a) 1.10(3), B(1)-H(1b) 1.07(6).

§ The crystallographic information file for $\left[\mathrm{Ag}_{3}\left(\mu_{3}-\mathrm{H}\right)\left(\mu_{3}-\mathrm{BH}_{4}\right) \mathrm{L}^{\mathrm{Ph}}{ }_{3}\right] \mathrm{BF}_{4}$ has been deposited at the Cambridge Crystallographic Data Centre and assigned the code: CCDC 1419573. 
$\mu_{3}$-hydride $\mathrm{H}$, the opposing face of the trinuclear core has a $\mu_{3}$ borohydride with distorted tetrahedral geometry, the boron lies on the 3-fold axis of symmetry and three symmetry related hydrides (H1a) coordinate to the three silver atoms. Related $\mu_{3}$-borohydride binding to the metal triangle of $\mathrm{Fe}(\mathrm{CO})_{3}$ fragments has been reported for the trinuclear cluster $\left[\mathrm{Fe}_{3}(\mu-\mathrm{H})\right.$ $\left.\left(\mu_{3}-\mathrm{BH}_{4}\right)(\mathrm{CO})_{9}\right]^{27}$ The boron-hydrogen bond lengths for $\mathrm{BH}_{4}{ }^{-}$ are: $\mathrm{B}(1)-\mathrm{H}(1 \mathrm{a})$ 1.10(3) $\AA$ and $\mathrm{B}(1)-(\mathrm{H} 1 \mathrm{~b})$ 1.07(6) $\AA$. There are two types of bond angles in the $\mathrm{BH}_{4}{ }^{-}$tetrahedron: (i) $\mathrm{H}(1 \mathrm{a})$ $\mathrm{B}(1)-\mathrm{H}(1 \mathrm{a}) 110.1(16)^{\circ}$ and (ii) $\mathrm{H}(1 \mathrm{a})-\mathrm{B}(1)-\mathrm{H}(1 \mathrm{~b})$ 108.9(16) ${ }^{\circ}$. The tetrahedral face $\mathrm{H}(1 \mathrm{a})-\mathrm{H}(1 \mathrm{a})-\mathrm{H}(1 \mathrm{a})$, is parallel to the larger $\mathrm{Ag}(1)-\mathrm{Ag}(1)-\mathrm{Ag}(1)$ plane. Each of the three hydrogen atoms of $\mathrm{BH}_{4}{ }^{-}, \mathrm{H}(1 \mathrm{a})$, are individually coordinated to one silver(I) ion where $\mathrm{H}(1 \mathrm{a})-\mathrm{Ag}(1)$ is $2.17(3) \AA$. The core is surrounded by three $\mu_{2}$-bridging phosphine ligands which coordinate to two silver(I) ions through $\mathrm{P}(1)$ and $\mathrm{P}(2)$ : $A g(1)-\mathrm{P}(1)$ is 2.4483(5) $\AA$ and $\operatorname{Ag}(1)-\mathrm{P}(2)$ is $2.4486(5) \AA$. The distance between $\mathrm{P}(1)$ and $\mathrm{P}(2)$ within the chelate ring is $3.041 \AA$ and the $\mathrm{P}(1)-\mathrm{C}(20)-\mathrm{P}(2)$ angle is $110.8(1)^{\circ} . \mathrm{P}(1)$ is below the plane of the trinuclear core and both $\mathrm{C}(20)$ and $\mathrm{P}(2)$ are above the plane with $\mathrm{C}(20)$ above $\mathrm{P}(2)$.

The phenyl rings extending from the phosphorus atoms adopt one of three distinct geometrical conformations. Both $\mathrm{P}(1)$ and $\mathrm{P}(2)$ have one phenyl ring towards the $\mu_{3}$-hydride. A pseudoequatorial phenyl ring in regards to the $\mathrm{Ag}_{3}$ triagnular plane extends from $\mathrm{P}(1)$. One phenyl ring from each $\mathrm{P}(2)$ extends toward the $\mu_{3}$-borohydride.

The structures of $\left[\mathrm{Ag}_{3}\left(\mu_{3}-\mathrm{H}\right)\left(\mu_{3}-\mathrm{BH}_{4}\right) \mathrm{L}_{3}^{\mathrm{Ph}}\right]^{+},\left[\mathrm{Ag}_{3}\left(\mu_{3}-\mathrm{D}\right) \mathrm{L}_{3}^{\mathrm{Ph}}\right]^{2+}$ (ref. 10) and $\left[\mathrm{Ag}_{3}\left(\mu_{3}-\mathrm{H}\right)\left(\mu_{3}-\mathrm{Cl}\right) \mathrm{L}_{3}^{\mathrm{Ph}}\right]^{+}$(ref. 9) are compared in Table 1. All structures consist of a trinuclear silver(I) core and maintain a triangular geometry. The dication $\left[\mathrm{Ag}_{3}\left(\mu_{3}-\mathrm{D}\right) \mathrm{L}_{3}^{\mathrm{Ph}}\right]^{2+}$ has the longest $\mathrm{Ag}-\mathrm{Ag}$ and $\mathrm{Ag}-\mathrm{P}$ interactions at 3.1193 and $2.4632 \AA$ respectively. All hydrides coordinate as $\mu_{3}$-bridging ligands where the longest $\mathrm{Ag}-\mathrm{H}$ interaction exists in $\left[\mathrm{Ag}_{3}\left(\mu_{3}-\mathrm{H}\right)\right.$ $\left.\left(\mu_{3}-\mathrm{Cl}\right) \mathrm{L}_{3}^{\mathrm{Ph}}\right]^{+}$at 1.91(2) $\AA$.

The $\mathrm{BF}_{4}{ }^{-}$counterion is disordered over two crystallographic special positions, a -3 site with normal $1 / 6$ occupancy and on a 3 -fold axis with $50 \%$ the normal occupancy of $1 / 3$, with the same position occupied the other $50 \%$ by a molecule of acetonitrile. The relative occupancy at these special positions were supported by SQUEEZE calculations ${ }^{29}$ which were not used to remove these disordered components. The Ag bound hydride and $\mathrm{BH}_{4}$ hydrides were located on Fourier difference maps and refined isotropically without restraint.

Table 1 A comparison of selected bond lengths $(\AA)$ and angles $\left(^{\circ}\right)$ with estimated standard deviations in parentheses for $\left[\mathrm{Ag}_{3}\left(\mu_{3}-\mathrm{D}\right) \mathrm{L}^{\mathrm{Ph}}{ }_{3}\right]\left(\mathrm{BF}_{4}\right)_{2},{ }^{9}$ $\left[\mathrm{Ag}_{3}\left(\mu_{3}-\mathrm{H}\right)\left(\mu_{3}-\mathrm{Cl}\right) \mathrm{LP}_{3}\right] \mathrm{BF}_{4}{ }^{10}$ and $\left[\mathrm{Ag}_{3}\left(\mu_{3}-\mathrm{H}\right)\left(\mu_{3}-\mathrm{BH}_{4}\right) \mathrm{L}^{\mathrm{Ph}}{ }_{3}\right] \mathrm{BF} \mathrm{F}_{4}$

\begin{tabular}{llll}
\hline & $\begin{array}{l}{\left[\mathrm{Ag}_{3}\left(\mu_{3}-\mathrm{D}\right)-\right.} \\
\left.\mathrm{L}_{3}\right]^{2+}\end{array}$ & $\begin{array}{l}{\left[\mathrm{Ag}_{3}\left(\mu_{3}-\mathrm{H}\right)-\right.} \\
\left(\mu_{3}-\mathrm{Cl}^{2+} \mathrm{L}^{\mathrm{Ph}}\right]^{+}\end{array}$ & $\begin{array}{l}{\left[\mathrm{Ag}_{3}\left(\mu_{3}-\mathrm{H}\right)-\right.} \\
\left.\left(\mu_{3}-\mathrm{BH}_{4}\right) \mathrm{L}^{\mathrm{Ph}}\right]_{3}\end{array}$ \\
\hline $\mathrm{Ag}-\mathrm{Ag}$ & 3.1193 & $2.8988(2)$ & $2.9100(3)$ \\
$\mathrm{Ag}-(\mathrm{H} / \mathrm{D})$ & 1.83 & $1.91(2)$ & $1.93(3)$ \\
$\mathrm{Ag}-\left(\mathrm{Cl} / \mathrm{BH}_{4}\right)$ & $\mathrm{NA}$ & $2.859(1)$ & $2.17(3)$ \\
$\mathrm{Ag}-\mathrm{P}$ & 2.4632 & $2.4421(9)$ & $2.4486(5)$
\end{tabular}

\section{Unimolecular gas-phase chemistry of $\left[\mathrm{Ag}_{3}(\mathbf{H})\left(\mathrm{BH}_{4}\right) \mathrm{L}_{3}\right]^{+}$}

Given that $\mathrm{AgBH}_{4}$ is known to undergo thermal decomposition reactions that liberate $\mathrm{BH}_{3}$ (eqn (2)), ${ }^{1,23}$ we were interested in examining whether such reactions occur in the gas phase for isolated, stoichiometrically well defined cluster cations. Thus, CID was carried out in a $2 \mathrm{D}$ linear ion trap to probe the lowenergy fragmentation pathways of $\left[\mathrm{Ag}_{3}(\mathrm{H})\left(\mathrm{BH}_{4}\right) \mathrm{L}_{3}\right]^{+}$, where the cluster identity has been confirmed by high resolution mass spectrometry (HRMS).

Mass selection and subsequent CID of $\left[\mathrm{Ag}_{3}(\mathrm{H})\left(\mathrm{BH}_{4}\right) \mathrm{L}_{3}^{\mathrm{Ph}}\right]^{+}$ $(\mathrm{m} / \mathrm{z}$ 1493, HRMS (ESI Fig. S1a and $\mathrm{b} \dagger)$ ) to $c a$. $50 \%$ relative intensity yields $\left[\mathrm{Ag}_{3}(\mathrm{H})\left(\mathrm{BH}_{4}\right) \mathrm{L}_{2}^{\mathrm{Ph}}\right]^{+}(m / z$ 1109, HRMS (ESI Fig. S1c and $\mathrm{d} \dagger$ )) via neutral ligand loss (eqn (5)) as the main fragmentation channel. $\left[\mathrm{Ag}_{3}(\mathrm{H})_{2} \mathrm{~L}_{2}{ }_{2}\right]^{+}(m / z$ 1095, HRMS (ESI Fig. S17a and $\left.\mathrm{b}_{\dagger} \dagger\right)$ ), $\left[\mathrm{Ag}_{3}(\mathrm{H})\left(\mathrm{BH}_{4}\right) \mathrm{L}^{\mathrm{Ph}}\right]^{+}(\mathrm{m} / \mathrm{z}$ 723, (ESI Fig. S1e and $\left.\mathrm{f}^{\dagger}\right)$ ) and $\left[\mathrm{Ag}_{3}(\mathrm{H})_{2} \mathrm{~L}^{\mathrm{Ph}}\right]^{+}(\mathrm{m} / z$ 709, (ESI Fig. S17c and $\mathrm{d} \dagger)$ ); $\left[\mathrm{Ag}_{2}(\mathrm{H}) \mathrm{L}^{\mathrm{Ph}}\right]^{+}\left(\mathrm{m} / \mathrm{z}\right.$ 601) and; $\left[\mathrm{AgL}^{\mathrm{Ph}}\right]^{+}(\mathrm{m} / z$ 491) are all also observed.

The main fragmentation channel of $\left[\mathrm{Ag}_{3}(\mathrm{H})\left(\mathrm{BH}_{4}\right) \mathrm{L}_{3}^{\mathrm{Me}}\right]^{+}(\mathrm{m} / z$ 747, HRMS (ESI Fig. S2 $\dagger$ )) involves neutral ligand loss (eqn (5)) to form $\left[\mathrm{Ag}_{3}(\mathrm{H})\left(\mathrm{BH}_{4}\right) \mathrm{L}_{2}^{\mathrm{Me}}\right]^{+}(\mathrm{m} / z$ 610, Fig. 3b). Other ions observed include $\left[\mathrm{Ag}_{3}(\mathrm{H})_{2} \mathrm{~L}_{2}\right]^{+}(m / z 596),\left[\mathrm{Ag}_{3}(\mathrm{H})\left(\mathrm{BH}_{4}\right) \mathrm{L}^{\mathrm{Me}}\right]^{+}$ $\left(\mathrm{m} / z\right.$ 475) and $\left[\mathrm{Ag}_{3}(\mathrm{H})_{2} \mathrm{~L}^{\mathrm{Me}}\right]^{+}(\mathrm{m} / z$ 461).

Energy-resolved CID (ERCID) was used in a 3D ion trap to determine whether the product ions in Fig. 3a are due to primary fragmentation pathways of $\left[\mathrm{Ag}_{3}(\mathrm{H})\left(\mathrm{BH}_{4}\right) \mathrm{L}_{3}^{\mathrm{Ph}}\right]^{+}$or secondary fragmentation of primary fragment ions (ESI Fig. S18†). The onset of ligand loss (eqn (5)) begins at ca. $0.6 \mathrm{~V}$ and continues to steadily increase up until $0.8 \mathrm{~V}$ (ESI Fig. S18 $\dagger$ ). An increase in the collision voltage beyond this point results in the consumption of $\left[\mathrm{Ag}_{3}(\mathrm{H})\left(\mathrm{BH}_{4}\right) \mathrm{L}_{2}\right]^{+}(m / z$ 1109) and the increase of $\left[\mathrm{Ag}_{3}(\mathrm{H})_{2} \mathrm{~L}_{2}\right]^{+}(\mathrm{m} / \mathrm{z}$ 1095). These results suggest that the primary product ion upon CID of $\left[\mathrm{Ag}_{3}(\mathrm{H})\left(\mathrm{BH}_{4}\right) \mathrm{L}_{3}^{\mathrm{Ph}}\right]^{+}$arises from ligand loss and that ions of

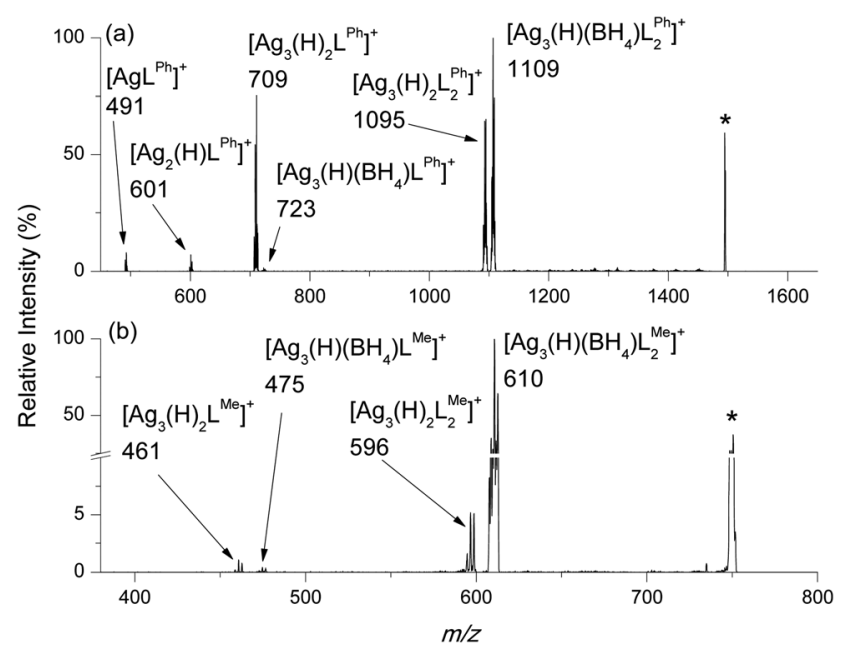

Fig. 3 LTQ CID of (a) $\left[\mathrm{Ag}_{3}(\mathrm{H})\left(\mathrm{BH}_{4}\right) \mathrm{L}_{3}\right]^{+}, m / z$ 1493; (b) $\left[\mathrm{Ag}_{3}(\mathrm{H})\left(\mathrm{BH}_{4}\right) \mathrm{L}_{3}\right]^{+}$, $\mathrm{m} / \mathrm{z}$ 747. The most intense peak in the cluster is represented by the $\mathrm{m} / \mathrm{z}$ value. *Refers to the mass-selected precursor ion. 
lower $\mathrm{m} / \mathrm{z}$ are from subsequent secondary fragmentation of $\left[\mathrm{Ag}_{3}(\mathrm{H})_{2} \mathrm{~L}_{2}\right]^{+}(m / z$ 1095).

$$
\left[\mathrm{Ag}_{3}(\mathrm{H})\left(\mathrm{BH}_{4}\right) \mathrm{L}_{3}\right]^{+} \rightarrow\left[\mathrm{Ag}_{3}(\mathrm{H})\left(\mathrm{BH}_{4}\right) \mathrm{L}_{2}\right]^{+}+\mathrm{L}
$$

\section{Unimolecular gas-phase chemistry of $\left[\mathrm{Ag}_{3}(\mathrm{H})\left(\mathrm{BH}_{4}\right) \mathrm{L}_{2}\right]^{+}$}

The primary product ions formed via ligand loss (eqn (5), Fig. 3) were mass selected and subjected to CID in the 2D ion trap (Fig. 4). Mass selection and subsequent CID of $\left[\mathrm{Ag}_{3}(\mathrm{H})\right.$ $\left.\left(\mathrm{BH}_{4}\right) \mathrm{L}_{2}^{\mathrm{Ph}}\right]^{+}(\mathrm{m} / \mathrm{z}$ 1109, Fig. 4a) to $\mathrm{ca}$. $30 \%$ relative intensity yields $\left[\mathrm{Ag}_{3}(\mathrm{H})_{2} \mathrm{~L}_{2}{ }^{\mathrm{Ph}}\right]^{+}(\mathrm{m} / z$ 1095) via neutral borane loss (eqn (5)) as a minor fragmentation channel and $\left[\mathrm{Ag}_{3}(\mathrm{H})_{2} \mathrm{~L}^{\mathrm{Ph}}\right]^{+}$ $\left(m / z\right.$ 709) as the main fragmentation channel; (ii) $\left[\mathrm{Ag}_{2}(\mathrm{H}) \mathrm{L}^{\mathrm{Ph}}\right]^{+}$ $\left(\mathrm{m} / z\right.$ 601) and; (iii) $\left[\mathrm{AgL}^{\mathrm{Ph}}\right]^{+}(\mathrm{m} / z$ 491) are all also observed. The main fragmentation channel upon CID of $\left[\mathrm{Ag}_{3}(\mathrm{H})_{2} \mathrm{~L}_{2}^{\mathrm{Me}}\right]^{+}$ ( $m / z$ 596, Fig. 4b) involves neutral borane loss (eqn (6)). Other ions observed include $\left[\mathrm{Ag}_{3}(\mathrm{H})\left(\mathrm{BH}_{4}\right) \mathrm{L}^{\mathrm{Me}}\right]^{+}(\mathrm{m} / z$ 475), and $\left[\mathrm{Ag}_{3}(\mathrm{H})_{2} \mathrm{~L}^{\mathrm{Me}}\right]^{+}(\mathrm{m} / z$ 461).

Once again, ERCID was used in a 3D ion trap to determine which of the product ions observed in Fig. 4a were primary (ESI Fig. $\left.\mathrm{S}^{4} \dagger\right)$. $\left[\mathrm{Ag}_{3}(\mathrm{H})_{2} \mathrm{~L}_{2}^{\mathrm{Ph}}\right]^{+}(m / z$ 1095) begins to appear at $0.5 \mathrm{~V}$ upon CID $\left[\mathrm{Ag}_{3}(\mathrm{H})\left(\mathrm{BH}_{4}\right) \mathrm{L}_{2}^{\mathrm{Ph}}\right]^{+}(m / z$ 1109), which corresponds to $\mathrm{BH}_{3}$ loss (eqn (6)). A minor primary fragmentation channel assigned to neutral ligand loss (eqn (7)) is observed at around $0.6 \mathrm{~V}$. Although decomposition reactions of coordinated ligands in metal complexes and clusters have been well studied in the gas-phase,$^{30,31}$ this appears to be the first experimental report on the gas-phase decomposition of a coordinated $\mathrm{BH}_{4}{ }^{-}$ligand via $\mathrm{BH}_{3}$ loss. This reaction is related to that described by Wiberg and Henle (eqn (2)). ${ }^{1}$

$$
\begin{aligned}
{\left[\mathrm{Ag}_{3}(\mathrm{H})\left(\mathrm{BH}_{4}\right) \mathrm{L}_{2}\right]^{+} } & \rightarrow\left[\mathrm{Ag}_{3}(\mathrm{H})_{2} \mathrm{~L}_{2}\right]^{+}+\mathrm{BH}_{3} \\
{\left[\mathrm{Ag}_{3}(\mathrm{H})\left(\mathrm{BH}_{4}\right) \mathrm{L}_{2}\right]^{+} } & \rightarrow\left[\mathrm{Ag}_{3}(\mathrm{H})\left(\mathrm{BH}_{4}\right) \mathrm{L}\right]^{+}+\mathrm{L}
\end{aligned}
$$

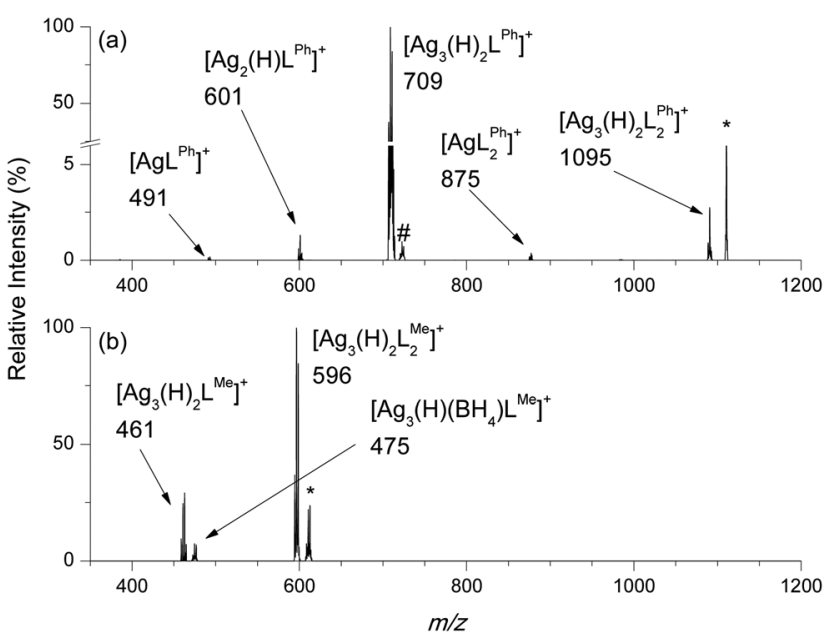

Fig. 4 LTQ CID of: (a) $\left.\left[\mathrm{Ag}_{3}(\mathrm{H})\left(\mathrm{BH}_{4}\right) \mathrm{L}^{\mathrm{Ph}}\right]_{2}\right]^{+}, m / z$ 1109); (b) $\left[\mathrm{Ag}_{3}(\mathrm{H})\left(\mathrm{BH}_{4}\right) \mathrm{L}^{\mathrm{Me}}{ }_{2}\right]^{+}$, $\mathrm{m} / \mathrm{z} 610$. The most intense peak in the cluster is represented by the $\mathrm{m} / \mathrm{z}$ value. *Refers to the mass-selected precursor ion. \#Refers to background noise.

\section{Unimolecular gas-phase chemistry of $\left[\mathrm{Ag}_{3}(\mathrm{H})\left(\mathrm{BH}_{4}\right) \mathrm{L}\right]^{+}$}

$\left[\mathrm{Ag}_{3}(\mathrm{H})\left(\mathrm{BH}_{4}\right) \mathrm{L}^{\mathrm{Ph}}\right]^{+}(\mathrm{m} / \mathrm{z}$ 723), formed via sequential ligand losses (eqn (4) and (6)), was mass selected and allowed to undergo CID. The sole fragmentation channel observed is due to the loss of neutral $\mathrm{BH}_{3}$ (eqn (8)) (ESI Fig. S20†).

$$
\left[\mathrm{Ag}_{3}(\mathrm{H})\left(\mathrm{BH}_{4}\right) \mathrm{L}\right]^{+} \rightarrow\left[\mathrm{Ag}_{3}(\mathrm{H})_{2} \mathrm{~L}\right]^{+}+\mathrm{BH}_{3}
$$

\section{Unimolecular gas-phase chemistry of $\left[\mathrm{Ag}_{3}(\mathrm{H})_{2} \mathrm{~L}_{n}\right]^{+}$}

The dihydride clusters $\left[\mathrm{Ag}_{3}(\mathrm{H})_{2} \mathrm{~L}_{n}^{\mathrm{Ph}}\right]^{+}$where $n=2$, 1 were subjected to ERCID using a 3D ion trap (ESI Fig. S21 and S22 $\dagger$ ). The major primary fragmentation of $\left[\mathrm{Ag}_{3}(\mathrm{H})_{2} \mathrm{~L}_{2}\right]^{+}(\mathrm{m} / \mathrm{z}$ 1095) occurs via ligand loss (eqn (9)), with an onset requiring ca. $0.6 \mathrm{~V}$. In contrast, The major primary fragmentation of $\left[\mathrm{Ag}_{3}(\mathrm{H})_{2} \mathrm{~L}^{\mathrm{Ph}}\right]^{+} \quad(\mathrm{m} / \mathrm{z}$ 708) involves $\mathrm{AgH}$ loss, as previously described, ${ }^{32}$ with the onset of fragmentation occurring at ca. $0.4 \mathrm{~V}$.

$$
\begin{gathered}
{\left[\mathrm{Ag}_{3}(\mathrm{H})_{2} \mathrm{~L}_{2}\right]^{+} \rightarrow\left[\mathrm{Ag}_{3}(\mathrm{H})_{2} \mathrm{~L}\right]^{+}+\mathrm{L}} \\
{\left[\mathrm{Ag}_{3}(\mathrm{H})_{2} \mathrm{~L}\right]^{+} \rightarrow\left[\mathrm{Ag}_{2}(\mathrm{H}) \mathrm{L}\right]^{+}+\mathrm{AgH}}
\end{gathered}
$$

\section{Computational study of $\mathrm{BH}_{4}{ }^{-}$decomposition triggered via ligand loss in the clusters $\left[\mathrm{Ag}_{3}(\mathrm{H})\left(\mathrm{BH}_{4}\right) \mathrm{L}_{n}^{\mathrm{Me}}\right]^{+}(n=1-3)$}

To better understand how the number of diphosphine ligands, $n$, in the clusters, $\left[\mathrm{Ag}_{3}(\mathrm{H})\left(\mathrm{BH}_{4}\right) \mathrm{L}_{n}\right]^{+}$, influence the competition between decomposition of the ligated $\mathrm{BH}_{4}{ }^{-}$(eqn (11)) versus loss of a ligand (eqn (12)), we turned to DFT calculations to examine the structures and energetics of the reactants and products of eqn (11) and (12) for the case of clusters containing $\mathrm{L}^{\mathrm{Me}}$ ligands. The initial geometry for $\left[\mathrm{Ag}_{3}(\mathrm{H})\left(\mathrm{BH}_{4}\right) \mathrm{L}_{3}^{\mathrm{Me}}\right]^{+}$was that related to the core structure from the X-ray structure for $\mathbf{1}$. Thus changing the phosphine substitutent from $\mathrm{Ph}$ to $\mathrm{Me}$ has little effect on the core structure. To calculate fragment ion structures, either $\mathrm{BH}_{3}$ or $\mathrm{L}^{\mathrm{Me}}$ was removed and the resultant fragment was allowed to fully optimise. $\mathbf{|} \|$

$$
\begin{gathered}
{\left[\mathrm{Ag}_{3}(\mathrm{H})\left(\mathrm{BH}_{4}\right) \mathrm{L}_{n}\right]^{+} \rightarrow\left[\mathrm{Ag}_{3}(\mathrm{H})_{2} \mathrm{~L}_{n}\right]^{+}+\mathrm{BH}_{3}} \\
{\left[\mathrm{Ag}_{3}(\mathrm{H})\left(\mathrm{BH}_{4}\right) \mathrm{L}_{n}\right]^{+} \rightarrow\left[\mathrm{Ag}_{3}(\mathrm{H})\left(\mathrm{BH}_{4}\right) \mathrm{L}_{n-1}\right]^{+}+\mathrm{L}}
\end{gathered}
$$

To understand why $\mathrm{BH}_{4}{ }^{-}$in $\left[\mathrm{Ag}_{3}(\mathrm{H})\left(\mathrm{BH}_{4}\right) \mathrm{L}_{3}\right]^{+}$bridges all three $\mathrm{Ag}$ atoms via three separate two-electron, two-centre

ๆWhile there is no significant change in the DFT calculated gas-phase structure of $\left[\mathrm{Ag}_{3}(\mathrm{H})\left(\mathrm{BH}_{4}\right) \mathrm{L}^{\mathrm{Ph}}{ }_{3}\right]^{+}$compared to the X-ray structure, detailed discussions of the calculations are limited to the $\mathrm{L}^{\mathrm{Me}}$ systems, as the $\mathrm{Ag}-\mathrm{P}$ bond energies in $\left[\mathrm{Ag}_{3}(\mathrm{H})\left(\mathrm{BH}_{4}\right) \mathrm{L}_{3}^{\mathrm{Ph}}\right]^{+}$are overestimated using the M06 functional. The same is also true when the B3LYP-D3BJ functional is applied. For example, the CID results show that loss of the phosphine ligand from $\left[\mathrm{Ag}_{3}(\mathrm{H})\left(\mathrm{BH}_{4}\right) \mathrm{L}^{\mathrm{Ph}}\right]_{3}^{+}$is preferred to the $\mathrm{BH}_{3}$ loss while both the M06 and B3LYP-D3BJ functionals predict a reverse trend. This inconsistency is likely to arise from the overestimation of the magnitude of dispersive interactions in $\left[\mathrm{Ag}_{3}(\mathrm{H})\left(\mathrm{BH}_{4}\right) \mathrm{L}_{3}^{\mathrm{Ph}}\right]^{+}$due to the presence of the aromatic rings.

$\|$ We have attempted to locate transition states for the $\mathrm{BH}_{3}$ loss reactions. In all cases we have been unable to locate a transition state and attempts led to the loss of $\mathrm{BH}_{3}$. 
$(2 \mathrm{e}, 2 \mathrm{c})$ bonds, the structure and bonding of this cluster was analysed based on simple electron counting rules. ${ }^{33-37}$ As expected, a transition metal centre with a $\mathrm{d}^{10}$ electron configuration has four empty orbitals. Two of these four are always available for ligand coordination to give linear complexes $\left[\mathrm{ML}_{2}\right]^{+}$. However, the availability of the other two orbitals depends on the identity of the L ligands. For example, if the $\mathrm{L}-\mathrm{M}-\mathrm{L}$ bond angle in $\left[\mathrm{ML}_{2}\right]^{+}$using the bidentate ligands is forced to be bent, the two extra orbitals become available and as a result the tetrahedral complex $\left[\mathrm{ML}_{4}\right]^{+}$is formed. Also, the monodentate L ligands with relatively weak $\sigma$-donor abilities increase the possibility of all four orbitals on the metal centre being available.

In $\left[\mathrm{Ag}_{3}(\mathrm{H})\left(\mathrm{BH}_{4}\right) \mathrm{L}_{3}\right]^{+}$, the presence of the three bidentate phosphine ligands render all the four empty orbitals on three $\mathrm{Ag}$ centres susceptible to coordination. In such a case, the cluster has $3 \times 4=12$ available orbitals. Six of these twelve orbitals are occupied by the phosphine ligands. Three of them are involved in interaction with the hydride ligand (a $\mu_{3}$-bridging ligand) via a four-centre two-electrons bonding mode. Finally, the last three orbitals on $\mathrm{Ag}$ centres overlap with three filled B-H $\sigma$ orbitals of $\mathrm{BH}_{4}{ }^{-}$, leading to coordination of $\mathrm{BH}_{4}{ }^{-}$in $\mu_{3}$-form. The 50 valence electron $\left[\mathrm{Ag}_{3}(\mathrm{H})\left(\mathrm{BH}_{4}\right) \mathrm{L}_{3}\right]^{+}$cluster is not expected to have direct metal-metal interactions, consistent with other related $M_{3} L_{6}$ clusters where $M$ has a $d^{10}$ electron configuration. ${ }^{35}$ This is highlighted by an examination of its HOMO, which suffers from the $\mathrm{Ag}-\mathrm{Ag}$ anti-bonding interactions derived from the silver $\mathrm{d}_{x z}$ orbitals (Fig. 6). The short $\mathrm{Ag}-\mathrm{Ag}$ bond distances in $\left[\mathrm{Ag}_{3}(\mathrm{H})\left(\mathrm{BH}_{4}\right) \mathrm{L}_{3}\right](2.971-2.993 \AA)$ can be mainly rationalised by the presence of the hydride ligand that creates the four-centre two-electron bonds with the $\mathrm{Ag}$ centres. A similar metal-metal bond distance was also observed by Harvey et al. in the $\left[\mathrm{Pd}_{3}\left(\mathrm{H}_{2} \mathrm{PCH}_{2} \mathrm{PH}_{2}\right)_{3}(\mathrm{CO})(\mathrm{H})\right]^{-}$ cluster (2.932 $\AA$ ), where the corresponding anti-bonding skeletal molecular orbitals are also fully occupied. ${ }^{38}$

With regards to the unimolecular fragmentation chemistry, the calculations indicate that the first loss of the ligand, $\mathrm{L}$ (eqn (12)), from $\left[\mathrm{Ag}_{3}(\mathrm{H})\left(\mathrm{BH}_{4}\right) \mathrm{L}_{3}^{\mathrm{Me}}\right]^{+}$results in transferring the hydride to $\mathrm{Ag}^{2}$ and causes this centre to adopt a mainly linear structure with a very weak interaction with $\mathrm{Ag}^{1}$ (Fig. 5). The presence of the very strong $\sigma$ donating hydride ligand on the $\mathrm{Ag}^{2}$ centre makes the two empty orbitals on $\mathrm{Ag}^{2}$ less available and thus does not allow $\mathrm{BH}_{4}{ }^{-}$to strongly interact with them. In this case, $\mathrm{BH}_{4}{ }^{-}$is only able to interact with the $\mathrm{Ag}^{1}$ and $\mathrm{Ag}^{3}$ centres to give a $\mu^{2}$-coordination mode (Fig. 5). If we ignore the weak interactions between $\mathrm{Ag}$ centres in $\left[\mathrm{Ag}_{3}(\mathrm{H})\left(\mathrm{BH}_{4}\right) \mathrm{L}_{2}^{\mathrm{Me}}\right]^{+}$, the $\mathrm{Ag}^{1}$ and $\mathrm{Ag}^{3}$ centres can be considered as three coordinate centres. For $\left[\mathrm{Ag}_{3}(\mathrm{H})\left(\mathrm{BH}_{4}\right) \mathrm{L}_{2}^{\mathrm{Me}}\right]^{+}$, the $\mathrm{Ag}^{2}-\mathrm{H} \sigma$ orbital interacts with one of the empty orbitals on $\mathrm{Ag}^{3}$ and creates a 3-centre 2-electron bond between two silver(I) ions via a $\mu_{2}$-bridging hydride ligand.

From loss of a second $\mathrm{L}^{\mathrm{Me}}$ ligand, bonding in the product $\left[\mathrm{Ag}_{3}(\mathrm{H})\left(\mathrm{BH}_{4}\right) \mathrm{L}^{\mathrm{Me}}\right]^{+}$can be viewed as interaction of the linear complex $\left[\mathrm{BH}_{4}-\mathrm{Ag}^{3}-\mathrm{H}\right]^{-}$with $\left[\mathrm{Ag}_{2} \mathrm{~L}^{\mathrm{Me}}\right]^{2+}$ (Fig. 5). In this cluster, an $\mathrm{Ag}^{3}-\mathrm{H} \sigma$ orbital interacts with an empty orbital on $\mathrm{Ag}^{2}$, and $\mathrm{BH}_{4}{ }^{-}$bridges $\mathrm{Ag}^{3}$ to $\mathrm{Ag}^{1}$ through three of its B-H bonds. There-

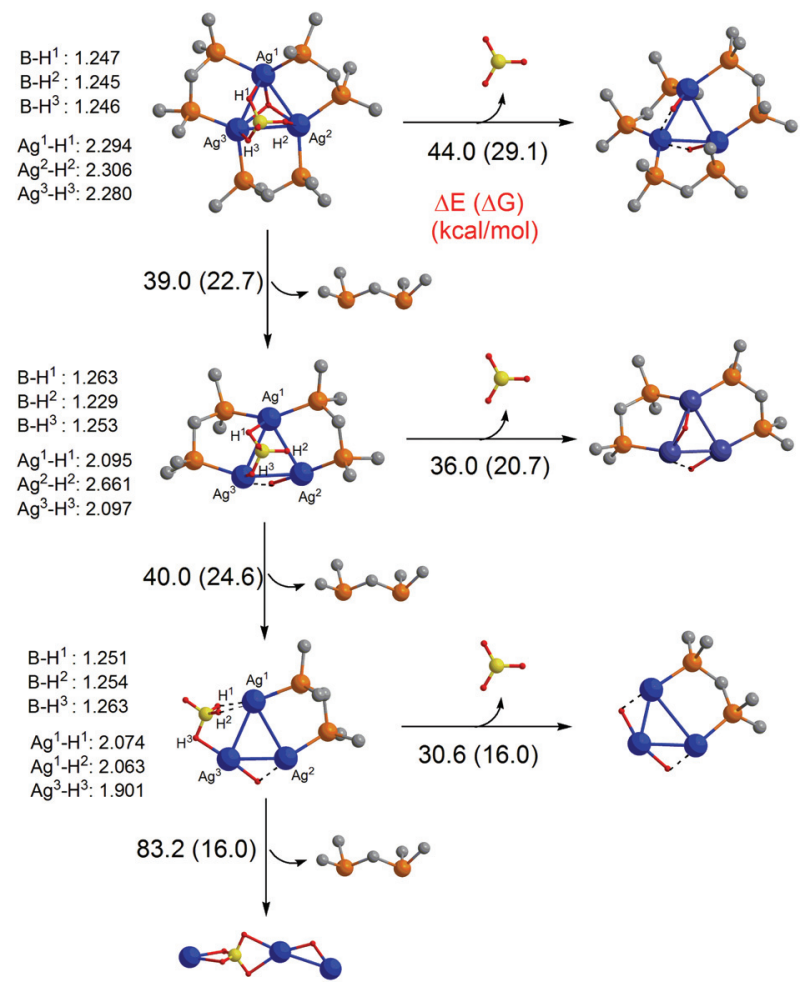

Fig. 5 DFT calculated structures and energetics for the competition between $\mathrm{BH}_{3}$ loss and $\mathrm{L}$ ligand loss. Hydrogen atoms on the $\mathrm{L}^{\mathrm{Me}}$ ligands are omitted for clarity.

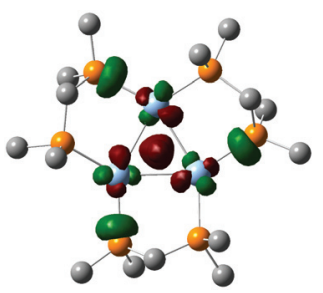

Fig. 6 Depiction of the DFT calculated HOMO of $\left[\mathrm{Ag}_{3}(\mathrm{H})\left(\mathrm{BH}_{4}\right) \mathrm{L}^{\mathrm{Me}}\right]^{+}$.

fore, each $\mathrm{Ag}(\mathrm{I})$ centre in $\left[\mathrm{Ag}_{3}(\mathrm{H})\left(\mathrm{BH}_{4}\right) \mathrm{L}^{\mathrm{Me}}\right]^{+}$experiences a linear two coordinated environment.

Our calculations show that, in excellent agreement with the CID data, the $\mathrm{BH}_{3}$ loss becomes easier as the number of ligands, L, decreases. The loss of the ligand, L, increases the electron deficiency of the metal centres, leading to the stronger coordination of $\mathrm{BH}_{4}{ }^{-}$to the $\mathrm{Ag}$ centres, as evident from the shorter $\mathrm{Ag}-\mathrm{H}\left(\mathrm{BH}_{4}\right)$ and longer $\mathrm{B}-\mathrm{H}$ bond distances in $\left[\mathrm{Ag}_{3}(\mathrm{H})\right.$ $\left.\left(\mathrm{BH}_{4}\right) \mathrm{L}^{\mathrm{Me}}\right]^{+}$(Fig. 5). In other words, ligand loss enhances the acidity of $\mathrm{Ag}$ centres and makes them more prone to compete with $\mathrm{BH}_{3}$ for hydride abstraction. The better the competition, the easier the $\mathrm{BH}_{3}$ loss.

In contrast to $\mathrm{BH}_{3}$ loss (eqn (11)) neutral ligand loss (eqn (12)) from $\left[\mathrm{Ag}_{3}(\mathrm{H})\left(\mathrm{BH}_{4}\right) \mathrm{L}^{\mathrm{Me}}\right]^{+}$is more difficult than that from $\left[\mathrm{Ag}_{3}(\mathrm{H})\left(\mathrm{BH}_{4}\right) \mathrm{L}_{3}^{\mathrm{Me}}\right]^{+}$and $\left[\mathrm{Ag}_{3}(\mathrm{H})\left(\mathrm{BH}_{4}\right) \mathrm{L}_{2}^{\mathrm{Me}}\right]^{+}$, supported by the 
DFT calculations. This difference can be rationalised in terms of the molecular orbital approach. ${ }^{39}$ In general, the HOMO of $\mathrm{d}^{10}$ complexes $\left(\mathrm{ML}_{n}\right)$ with a coordination number greater than two $(n>2)$ suffers from a slight anti-bonding interaction between $\mathrm{L}$ and $\mathrm{M}$, leading to weakening of the $\mathrm{M}-\mathrm{L}$ bonds. However, this anti-bonding interaction disappears in linear $\mathrm{d}^{10}-\mathrm{ML}_{2}$ complexes, causing the $\mathrm{M}-\mathrm{L}$ bonds in $\mathrm{ML}_{2}$ to be much stronger than those in $\mathrm{ML}_{3}$ and $\mathrm{ML}_{4}$. As mentioned above, clusters $\left[\mathrm{Ag}_{3}(\mathrm{H})\left(\mathrm{BH}_{4}\right) \mathrm{L}_{3}^{\mathrm{Me}}\right]^{+}$and $\left[\mathrm{Ag}_{3}(\mathrm{H})\left(\mathrm{BH}_{4}\right) \mathrm{L}_{2}^{\mathrm{Me}}\right]^{+}$ have the $\mathrm{Ag}$ centres not present as two-coordinate, and thus the loss of the ligand, L, from these clusters is relatively easy. By contrast, all the $\mathrm{Ag}$ centres in $\left[\mathrm{Ag}_{3}(\mathrm{H})\left(\mathrm{BH}_{4}\right) \mathrm{L}^{\mathrm{Me}}\right]^{+}$are mainly two-coordinate, thereby not having the relevant anti-bonding interaction, forming very strong $\mathrm{M}-\mathrm{L}$ bonds.

\section{Conclusions}

The sodium borohydride induced reduction of silver(I) salts to form nanoparticles has been described as a "black-box" synthesis. ${ }^{19}$ While it is now well established that there are different growth stages, ${ }^{18-20}$ the actual molecular species associated during growth to nanoparticles and the mechanisms for growth are not fully understood. By studying the formation and reactions of small ligand protected nanoclusters, we are able to better understand the fundamental interactions between silver salts and borohydride.

We have previously shown that $\mathrm{BH}_{4}{ }^{-}$is a source of hydride for $\left[\mathrm{Ag}_{3}\left(\mu_{3}-\mathrm{H}\right) \mathrm{L}_{3}^{\mathrm{Ph}}\right]^{2+}$ (ref. 10) and $\left[\mathrm{Ag}_{3}\left(\mu_{3}-\mathrm{H}\right)\left(\mu_{3}-\mathrm{Cl}\right) \mathrm{L}^{\mathrm{Ph}}{ }_{3}\right]^{+}$(ref. 9) at ambient conditions, however at $-10^{\circ} \mathrm{C}$ the decomposition of $\mathrm{BH}_{4}{ }^{-}$can be prevented and coordination to silver(I) ions can occur to yield $\left[\mathrm{Ag}_{3}\left(\mu_{3}-\mathrm{H}\right)\left(\mu_{3}-\mathrm{BH}_{4}\right) \mathrm{L}_{3}^{\mathrm{Ph}}\right] \mathrm{BF}_{4}$. This is the first

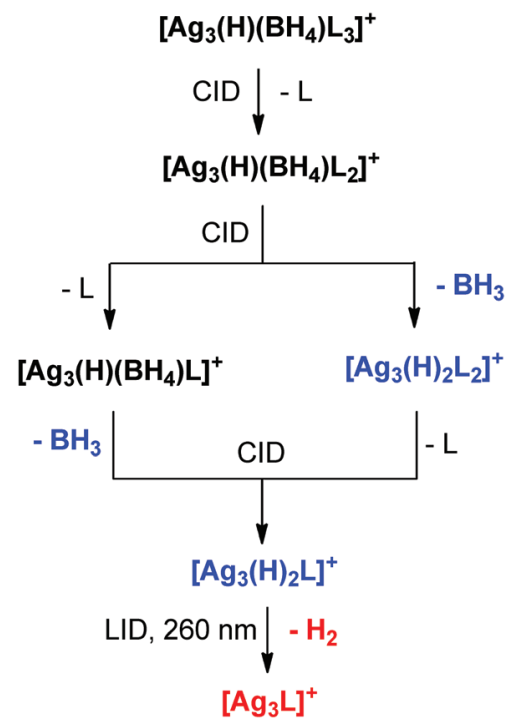

Scheme 2 Direct link established between mixed hydride/borohydride clusters (Black), dihydride clusters (Blue) and "all metal" clusters (Red) based on gas-phase unimolecular fragmentation reactions of mass selected clusters reported here using CID and in ref. 32 using laserinduced dissociation (LID). silver nanocluster containing a "captured" borohydride anion, and may have relevance to binding of $\mathrm{BH}_{4}{ }^{-}$to silver nanoparticle surfaces, ${ }^{20,21}$ or bulk silver metal surfaces. ${ }^{40}$ Given that nanoclusters such as $\left[\left\{\mathrm{Ag}_{7}\left(\mu_{4}-\mathrm{H}\right)\left(\mathrm{E}_{2} \mathrm{P}(\mathrm{OR})_{2}\right\}_{6}\right]\right.$ are precursors to further growth into silver nanoparticles, ${ }^{21}$ it will be interesting to establish whether the nanoclusters $\left[\mathrm{Ag}_{3}\left(\mu_{3}-\mathrm{H}\right)\right.$ $\left.\left(\mu_{3}-\mathrm{Cl}\right) \mathrm{L}^{\mathrm{Ph}}{ }_{3}\right] \mathrm{BF}_{4},{ }^{9} \quad\left[\mathrm{Ag}_{3}\left(\mu_{3}-\mathrm{H}\right) \mathrm{L}^{\mathrm{Ph}}{ }_{3}\right]\left(\mathrm{BF}_{4}\right)_{2},{ }^{10}$ and $\left[\mathrm{Ag}_{3}\left(\mu_{3}-\mathrm{H}\right)-\right.$ $\left.\left(\mu_{3}-\mathrm{BH}_{4}\right) \mathrm{L}^{\mathrm{Ph}}{ }_{3}\right] \mathrm{BF}_{4}$ can further grow into silver nanoparticles.

The current and previous ${ }^{32}$ gas-phase experiments and DFT calculations on $\left[\mathrm{Ag}_{3}(\mathrm{H})_{2-x}\left(\mathrm{BH}_{4}\right)_{x} \mathrm{~L}_{n}\right]^{+}$clusters provide a direct link between mixed hydride/borohydride silver clusters $(x=1)$, dihydride silver clusters $(x=0)^{32}$ and silver clusters via discrete unimolecular reactions occurring for isolated clusters (Scheme 2). Thus CID triggers loss of the ligand, L (eqn (12)), resulting in a change in the binding mode(s) of the $\mathrm{H}$ and $\mathrm{BH}_{4}$ ligands (Fig. 5). Perhaps related reactions occur at the surfaces of silver nanoparticles, which might drive the development of catalysts for hydrogen storage applications. ${ }^{41}$

\section{Experimental}

\section{Synthesis of solution phase silver clusters for MS analyses}

Silver(I) tetrafluoroborate $(1.9 \mathrm{mg}, 0.010 \mathrm{mmol})$ and bis(diphenylphosphino)methane $(3.8 \mathrm{mg}, 0.010 \mathrm{mmol})$ in $20 \mathrm{~mL}$ acetonitrile were added to a $25 \mathrm{~mL}$ Quickfit Erlenmeyer flask equipped with a magnetic stirrer and stopper. The solution was cooled to $\mathrm{ca} .-10^{\circ} \mathrm{C}$ by immersing the reaction flask in an ice/water bath above the solvent level. All reagents were kept in the dark and flasks covered in foil. Sodium borohydride (5.7 $\mathrm{mg}, 0.150 \mathrm{mmol}$ ) was added as a powder and the solution changed colour from clear to light yellow.

\section{Synthesis of crystalline $\left[\mathrm{Ag}_{3}(\mathrm{H})\left(\mathrm{BH}_{4}\right)\left(\mathrm{L}^{\mathrm{Ph}}\right)_{3}\right] \mathrm{BF}_{4}(1)$}

Silver(I) tetrafluoroborate (194 mg, $1.0 \mathrm{mmol}$ ) and bis(diphenylphosphino)methane (384 mg, $1.0 \mathrm{mmol}$ ) in $100 \mathrm{~mL}$ acetonitrile were added to a $250 \mathrm{~mL}$ Quickfit round bottomed flask equipped with a magnetic stirrer and stopper. The solution was cooled to $-10{ }^{\circ} \mathrm{C}$ by immersing the reaction flask in an ice/water bath above the solvent level. All reagents were kept in the dark and flasks covered in foil. Sodium borohydride $(57.0 \mathrm{mg}, 1.50 \mathrm{mmol})$, was added as a powder and the solution changed colour from clear to light yellow over $c a .5$ minutes. The solution was filtered after stirring for 3 hours and frozen solid by immersing the flask in liquid nitrogen. While frozen, $100 \mathrm{~mL}$ of diethylether was added and the flask moved to the fridge. After 72 hours crystalline material was formed and characterised by X-ray crystallography.

\section{NMR spectroscopy experiments}

The NMR experiments were performed on a Bruker Avance 400 NMR spectrometer (400.13 $\mathrm{MHz}{ }^{1} \mathrm{H}$ frequency) equipped with a $5 \mathrm{~mm}$ triple resonance broadband probe $\left(\mathrm{BB} /{ }^{2} \mathrm{H}-{ }^{1} \mathrm{H} /{ }^{19} \mathrm{~F}\right)$. Solutions for analysis by NMR were prepared by dissolving $\left[\mathrm{Ag}_{3}\left(\mu_{3}-\mathrm{H}\right)\left(\mu_{3}-\mathrm{BH}_{4}\right) \mathrm{L}_{3}{ }_{3}\right] \mathrm{BF}_{4}$ in $0.6 \mathrm{ml}$ of deuteroacetonitrile. NMR experiments were performed with the sample held at 
temperatures between $-15^{\circ} \mathrm{C}$ and $+25^{\circ} \mathrm{C}\left( \pm 0.1{ }^{\circ} \mathrm{C}\right)$. Chemical shifts for ${ }^{1} \mathrm{H}$ experiments are referenced to the residual protonated solvent signal $\left(\mathrm{CD}_{2} \mathrm{HCN}, \delta 1.94 \mathrm{ppm}\right) ;{ }^{11} \mathrm{~B}$ externally referenced to $\mathrm{BF}_{3} \cdot \mathrm{OEt}_{2}$ capillary in $\mathrm{CD}_{3} \mathrm{CN} ;{ }^{13} \mathrm{C}$ referenced to the solvent signal $\left(\mathrm{CD}_{3} \mathrm{CN}, \delta 1.39 \mathrm{ppm}\right) ;{ }^{19} \mathrm{~F}$ externally referenced to a $\mathrm{CFCl}_{3}$ in $\mathrm{CD}_{3} \mathrm{CN}(\delta 0.00 \mathrm{ppm}) ;{ }^{31} \mathrm{P}$ externally referenced to a $85 \% \mathrm{H}_{3} \mathrm{PO}_{4}$ capillary in $\mathrm{CDCl}_{3}(\delta 0.00 \mathrm{ppm})$. Oneand two-dimensional NMR experiments were acquired using standard Bruker library pulse sequences.

\section{Mass spectrometry}

Mass spectra were recorded using a Finnigan hybrid linear quadrupole (LTQ) Fourier transform ion cyclotron resonance (FTICR) mass spectrometer. The silver clusters prepared in the solution phase were diluted to $50 \mu \mathrm{M}$ and introduced into the mass spectrometer via a syringe pump set at a flow rate of $5 \mu \mathrm{L} \mathrm{min}^{-1}$ to the ESI capillary. The ESI conditions used, for optimum intensity of the target ions, typically were: spray voltage, 4.2-5.0 kV, capillary temperature, $250{ }^{\circ} \mathrm{C}$, nitrogen sheath gas pressure, 5 (arbitrary units), capillary voltage $25 \mathrm{~V}$, tube lens voltage $15 \mathrm{~V}$. Selected ions were transferred to the FTICR cell for accurate mass measurement with the use of selected ion monitoring (SIM) and selected reaction monitoring (SRM) to obtain the most reliable results. The unimolecular fragmentation of silver clusters was examined via CID. The mass-selected precursor ion was depleted to $10-20 \%$ using a normalised collision energy typically between $20-25 \%$ and a mass selection window of 15 Th to isolate the full range of isotopes due to boron and silver isotopes.

Energy resolved CID experiments were carried out using a Finnigan 3D ion trap (LCQ) mass spectrometer. The method of Broadbelt was adapted. ${ }^{42}$ The silver clusters were diluted to $50 \mu \mathrm{M}$ and introduced into the mass spectrometer via a syringe pump set at $5 \mu \mathrm{L} \mathrm{min}{ }^{-1}$ through a Finnigan ESI source. The source conditions used for optimum intensity of the target ions were: spray voltage $4.5-5.1 \mathrm{kV}$, capillary temperature $200{ }^{\circ} \mathrm{C}$, nitrogen sheath gas pressure, 50 (arbitrary units), capillary voltage $30 \mathrm{~V}$, tube lens voltage $-55 \mathrm{~V}$. The massselected precursor ion was isolated with a mass selection window of 15 Th. The normalised collision energy (NCE) was increased incrementally by $1.0 \%$ typically starting from a NCE where no fragmentation is observed, until reaching the NCE required for depleting the precursor ion to $<5 \%$ relative intensity. The NCE was converted to an amplitude of the resonance excitation RF voltage (tick amp) as described in the ESI. $\dagger$ The relative intensity of precursor and product ions were plotted as a function of the increasing amplitude to determine: (i) the onset of precursor fragmentation and (ii) the assignment of product ions as primary or secondary fragments of the massselected silver cluster.

\section{Crystallography}

Intensity data for compound $\mathbf{1}$ was collected on an Oxford Diffraction SuperNova CCD diffractometer using $\mathrm{Cu}-\mathrm{K} \alpha$ radiation, the temperature during data collection was maintained at 130.0(1) using an Oxford Cryostream cooling device. The structure was solved by direct methods and difference Fourier synthesis. ${ }^{43}$ The thermal ellipsoid plot was generated using the program ORTEP- ${ }^{44}$ integrated within the WINGX ${ }^{45}$ suite of programs. The $\mathrm{BF}_{4}{ }^{-}$counterion was disordered over two crystallographic special positions, a -3 site with normal 1/6 occupancy and on a 3 -fold axis with 50\% the normal occupancy of $1 / 3$, with the same position occupied the other $50 \%$ by a molecule of acetonitrile. The $\mathrm{Ag}$ bound hydride and $\mathrm{BH}_{4}$ hydrides were located on Fourier difference maps and refined isotropically without restraint.

Crystal data for 1: $\mathrm{C}_{75} \mathrm{H}_{71} \mathrm{~B}_{2} \mathrm{~F}_{4} \mathrm{P}_{6} \mathrm{Ag}_{3} \cdot\left(0.25 \mathrm{CH}_{3} \mathrm{CN}\right) \quad M=$ 1589.63, $T=130.0(2) \mathrm{K}, \lambda=1.54184 \AA$, cubic, space group $P a \overline{3}$, $a=24.1922(1) \AA, V=14158.79(18) \AA^{3}, Z=8, D_{\mathrm{c}}=1.491 \mathrm{mg} \mathrm{M}^{-3}$ $\mu(\mathrm{Cu}-\mathrm{K} \alpha) 8.296 \mathrm{~mm}^{-1}, F(000) 6428$, crystal size $0.17 \times 0.16 \times$ $0.09 \mathrm{~mm}$. 67033 reflections measured, 4996 independent reflections $\left(R_{\text {int }}=0.0442\right)$, the final $R$ was $0.0279[I>3(I) 4853$ data] and $\mathrm{w} R(F)$ (all data) was 0.0735 .

\section{Density functional theory}

Computational details. ${ }^{46-53}$ Gaussian $09^{46}$ was used to fully optimise all the structures reported in this paper at the M06 level of density functional theory. ${ }^{47,48}$ The effective-core potential of Hay and Wadt with a double- $\xi$ valence basis set (LANL2DZ) was chosen to describe Ag. The 6-31G(d) basis set was used for other atoms. Polarization functions were also added for $\mathrm{Ag}(\xi f=1.611)$. This basis set combination will be referred to as BS1. To further refine the energies obtained from the M06/BS1 calculations, we carried out single-point energy calculations for all of the structures with a larger basis set (BS2) at the M06 level of theory. BS2 utilises the def2-TZVP basis set on all atoms. Effective core potentials including scalar relativistic effects were used for silver atom. We have used the corrected potential energies obtained from the M06/ BS2//M06/BS1 calculations throughout the paper unless otherwise stated.

\section{Acknowledgements}

We thank the ARC for financial support via grants DP1096134 (to GNK) and DP150101388 (to RAJO and AJC). The authors gratefully acknowledge the generous allocation of computing time from the University of Tasmania and the National Computing Infrastructure. We thank Assoc. Prof. Paul Donnelly for useful discussions.

\section{Notes and references}

1 E. Wiberg and W. Henle, Z. Naturforsch., B: J. Chem. Sci., 1952, 7, 575-576.

2 J. C. Bommer and K. W. Morse, Inorg. Chem., 1980, 19, 587-593.

3 F. Cariati and L. Naldini, Gazz. Chim. Ital., 1965, 95, 201205. 
4 E. B. Lobkovskii, M. Y. Antipin, A. P. Borisov, V. D. Makhaev, K. N. Semenenko and Y. T. Struchkov, Koord. Khim., 1981, 7, 307-310.

5 C. W. Liu, H.-W. Chang, C.-S. Fang, B. Sarkar and J.-C. Wang, Chem. Commun., 2010, 46, 4571-4573.

6 C. W. Liu, H.-W. Chang, B. Sarkar, J.-Y. Saillard, S. Kahlal and Y.-Y. Wu, Inorg. Chem., 2010, 49, 468-475.

7 C. W. Liu, P.-K. Liao, C.-S. Fang, J.-Y. Saillard, S. Kahlal and J.-C. Wang, Chem. Commun., 2011, 47, 5831-5833.

8 B. K. Tate, C. M. Wyss, J. Bacsa, K. Kluge, L. Gelbaum and J. P. Sadighi, Chem. Sci., 2013, 4, 3068-3074.

9 A. Zavras, G. N. Khairallah, T. U. Connell, J. M. White, A. J. Edwards, P. S. Donnelly and R. A. J. O'Hair, Angew. Chem., Int. Ed., 2013, 52, 8391-8394.

10 A. Zavras, G. N. Khairallah, T. U. Connell, J. M. White, A. J. Edwards, R. J. Mulder, P. S. Donnelly and R. A. J. O'Hair, Inorg. Chem., 2014, 53, 7429-7437.

11 A. Desireddy, B. E. Conn, J. Guo, B. Yoon, R. N. Barnett, B. M. Monahan, K. Kirschbaum, W. P. Griffith, R. L. Whetten, U. Landman and T. P. Bigioni, Nature, 2013, 501, 399-402.

12 H. Yang, J. Lei, B. Wu, Y. Wang, M. Zhou, A. Xia, L. Zheng and N. Zheng, Chem. Commun., 2013, 49, 300-302.

13 H. Yang, Y. Wang, H. Huang, L. Gell, L. Lehtovaara, S. Malola, H. Hakkinen and N. Zheng, Nat. Commun., 2013, 4, 2422.

14 H. Yang, Y. Wang and N. Zheng, Nanoscale, 2013, 5, 26742677.

15 R. S. Dhayal, J.-H. Liao, Y.-C. Liu, M.-H. Chiang, S. Kahlal, J.-Y. Saillard and C. W. Liu, Angew. Chem., Int. Ed., 2015, 54, 3702-3706.

16 L. G. AbdulHalim, M. S. Bootharaju, Q. Tang, S. del Gobbo, R. G. AbdulHalim, M. Eddaoudi, D.-e. Jiang and O. M. Bakr, J. Am. Chem. Soc., 2015, 137, 11970-11975.

17 C. P. Joshi, M. S. Bootharaju, M. J. Alhilaly and O. M. Bakr, J. Am. Chem. Soc., 2015, 137, 11578-11581.

18 J. Polte, X. Tuaev, M. Wuithschick, A. Fischer, A. F. Thuenemann, K. Rademann, R. Kraehnert and F. Emmerling, ACS Nano, 2012, 6, 5791-5802.

19 M. Wuithschick, B. Paul, R. Bienert, A. Sarfraz, U. Vainio, M. Sztucki, R. Kraehnert, P. Strasser, K. Rademann, F. Emmerling and J. Polte, Chem. Mater., 2013, 25, 46794689.

20 D. L. Van Hyning and C. F. Zukowski, Langmuir, 1998, 14, 7034-7046.

21 J.-S. Seo, D.-M. Son, H. Lee, J. Kim and Y. Kim, Bull. Korean Chem. Soc., 2009, 30, 2651-2654.

22 Q.-Q. Xu, X.-Y. Dong, R.-W. Huang, B. Li, S.-Q. Zang and T. C. W. Mak, Nanoscale, 2015, 7, 1650-1654.

23 D. G. Musaev and K. Morokuma, Organometallics, 1995, 14, 3327-3334.

24 C. W. Liu, Y.-R. Lin, C.-S. Fang, C. Latouche, S. Kahlal and J.-Y. Saillard, Inorg. Chem., 2013, 52, 2070-2077.

25 V. D. Makhaev, Russ. Chem. Rev., 2000, 69, 727-746.

26 M. Besora and A. Lledós, Struct. Bonding, 2008, 130, 149-202.

27 J. Vites, C. Eigenbrot and T. P. Fehlner, J. Am. Chem. Soc., 1984, 106, 4633-4635.
28 A. J. Clark, A. Zavras, G. N. Khairallah and R. A. J. O'Hair, Int. J. Mass Spectrom., 2015, 378, 86-94.

29 P. Van der Sluis and A. L. Spek, Acta Crystallogr., Sect. A: Found. Crystallogr., 1990, A46, 194-201.

30 R. A. J. O'Hair, Gas Phase Ligand Fragmentation to Unmask Reactive Metallic Species, in Reactive Intermediates. MS Investigations in Solution, ed. L. S. Santos, Wiley-VCH, Weinheim, 2010, ch. 6, pp.199-227, ISBN: 978-3-527-32351-7.

31 R. A. J. O'Hair and N. J. Rijs, Acc. Chem. Res., 2015, 48, 329-340.

32 M. Girod, M. Krstić, R. Antoine, L. MacAleese, J. Lemoine, A. Zavras, G. N. Khairallah, V. Bonačić-Koutecký, P. Dugourd and R. A. J. O’Hair, Chem. - Eur. J., 2014, 20, 16626-16633.

33 D. M. P. Mingos, T. Slee and Z. Lin, Chem. Rev., 1990, 90, 383-402.

34 D. M. P. Mingos and D. J. Wales, Introduction to Cluster Chemistry, Prentice Hall, 1990.

35 D. G. Evans and D. M. P. Mingos, J. Organomet. Chem., 1982, 240, 321-327.

36 D. M. P. Mingos, J. Organomet. Chem., 2004, 689, 44204436.

37 F. K. Sheong, W.-J. Chen and Z. Lin, J. Organomet. Chem., 2015, 792, 93-101.

38 C. Cugnet, D. Lucas, E. Collange, B. Hanquet, A. Vallat, Y. Mugnier, A. Soldera and P. D. Harvey, Chem. - Eur. J., 2007, 13, 5338-5346.

39 H. Batebi, F. Zarkoob, K. Daraei, B. F. Yates and A. Ariafard, J. Organomet. Chem., 2013, 748, 89-97.

40 M. C. Sison Escaño, E. Gyenge, R. Lacdao Arevalo and H. Kasai, J. Phys. Chem. C, 2011, 115, 19883-19889.

41 W. Grochala and P. P. Edwards, Chem. Rev., 2004, 104, 1283-1315.

42 A. Colorado and J. Brodbelt, J. Am. Soc. Mass Spectrom., 1996, 7, 1116-1125.

43 G. M. Sheldrick, Acta Crystallogr., Sect. A: Found. Crystallogr., 2008, 64, 112-122.

44 L. J. Farrugia, J. Appl. Crystallogr., 1997, 30, 565.

45 L. J. Farrugia, J. Appl. Crystallogr., 1999, 32, 837-838.

46 M. J. Frisch, et al., Gaussian 09, revision D.01, Gaussian, Inc., Wallingford, CT, 2009. For the complete reference see the ESI. $\dagger$

47 Y. Zhao and D. G. Truhlar, Acc. Chem. Res., 2008, 41, 157167.

48 P. C. Hariharan and J. A. Pople, Theor. Chim. Acta, 1973, 28, 213-222.

49 A. W. Ehlers, M. Böhme, S. Dapprich, A. Gobbi, A. Höllwarth, V. Jonas, K. F. Köhler, R. Stegmann, A. Veldkamp and G. Frenking, Chem. Phys. Lett., 1993, 208, 111-114.

50 A. Höllwarth, M. Böhme, S. Dapprich, A. W. Ehlers, A. Gobbi, V. Jonas, K. F. Köhler, R. Stegmenn, A. Veldkamp, G. Frenking and R. Stegmann, Chem. Phys. Lett., 1993, 208, 237-240.

51 K. Fukui, J. Phys. Chem., 1970, 74, 4161-4163.

52 K. Fukui, Acc. Chem. Res., 1981, 14, 363-368.

53 S. Grimme, S. Ehrlich and L. Goerigk, J. Comput. Chem., 2011, 32, 1456-1465. 